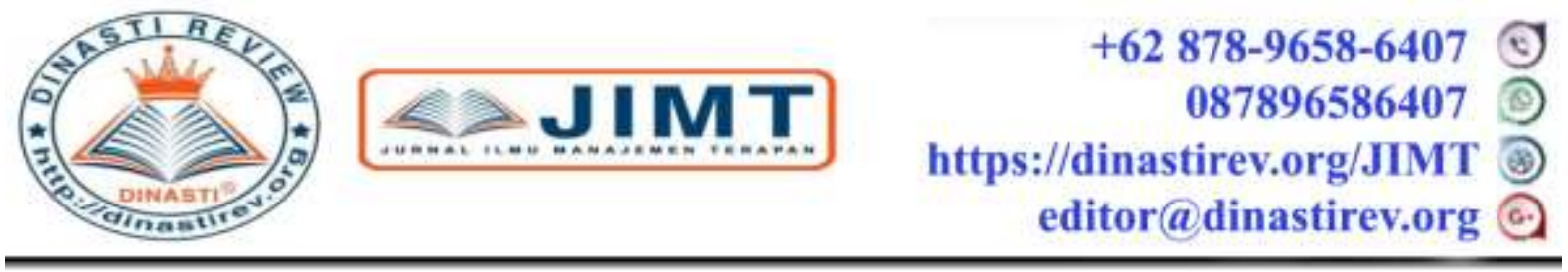

\title{
PENGARUH KONSEP DIRI TERHADAP MOTIVASI BELAJAR PADA MATA PELAJARAN IPS SMA NEGERI 7 MERANGIN
}

\author{
Rike Sundra $^{1)}$, Elvina Safitri ${ }^{2)}$
}

${ }^{1,2)}$ STKIP YPM Bangko

\section{ARTICLE INFORMATION \\ Received: 24 Agustus 2019 \\ Revised: 31 Agustus 2019 \\ Issued: 5 September 2019 \\ (filled in by Editor)}

Corresponding Author: First author E-mail: :

Rikesunra12@gmail.com Elvinasafitri87@gmail.com

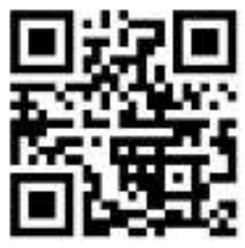

DOI:10.31933/JIMT

\begin{abstract}
Abstrak: This research is motivated by the low selfconcept of students which is characterized by a lack of student confidence in themselves and low motivation to learn in students. The purpose of this study was to determine the effect of self-concept on student learning motivation in social studies. The research method used is quantitative with simple linear regression analysis techniques. The research respondents were 50 high school students of SMA Negeri 7 Merangin. Data collection by researchers is done by questionnaire or questionnaire. Trials on the research instrument of the researcher are validity and reliability testing. The test for classical assumptions using the normality test and Linearity test with the help of SPPS application 20. The results showed that students' self-concepts have a significant influence on student motivation which is shown in the regression coefficient of 0.728 and the $\mathrm{R}$ Square coefficient of 0.403 is terminated.
\end{abstract}

Kata Kunci: : Self-Concept and Learning Motivation

\section{PENDAHULUAN}

Pendidikan merupakan salah satu komponen penting bagi setiap manusia dan tidak pernah berubah sampai kapanpun. Karena pendidikan sangat mendorong dalam mencerdaskan bangsa dan menghasilkan kepribadian yang diinginkan.

Terdapat pembentukan kepribadian manusia dengan menjadikan sumber daya yang berkompeten untuk kehidupan bangsa yang cerdas dan memperbaiki moral dan etika siswa. Dalam memperbaiki moral dan etika siswa juga perlu adanya kegiatan siswa yaitu kegiatan belajar dan mengajar antara siswa dengan tenaga pegajar disekolah unutuk mencapai keberhasilan dalam diri siswa.

Proses keberhasilan dalam pembelajaran tidak hanya melibatkan guru tetapi juga melibatkan kepribadian siswa serta peran motivasi didalam dirinya untuk mencapai pembelajaran yang baik/sempurna. Kemudian selain kepribadian siswa yang baik suasana kelas juga menjadi faktor rendahnya siswa dalam mengikuti pembelajaran. Maka kondisi siswa sangat diharapkan baik karena selain memicu dalam proses pembelajaran juga mempengaruhi motivasi belajar siswa itu sendiri, karena apabila 
kondisi sekolah ataupun kondisi siswa itu sendiri kurang baik otomatis motivasi belajarnya akan berkurang.

Selain kondisi siswa yang baik salah satu faktor penyebab rendahnya motivasi belajar dikarenakan kurangnya keyakinan siswa terhadap diri nya sendiri dan masih banyak juga siswa yang mengeluh apabila diberikan tugas oleh guru serta siswa banyak bergantung pada orang lain dan tidak mau berusaha sendiri, maka itulah yang menyebabkan rendahnya semangat dalam diri siswa untuk mengikuti pembelajaran, sehingga motivasi belajar siswa di SMA Negeri 7 Merangin rendah.

Fenomena yang terlihat di SMA Negeri 7 Merangin, masih terdapat Nilai ulangan siswa yang masih rendah terutama di kelas XI dan XII IPS. Berdasarkan fenomena tersebut peneliti tertarik melakukan penelitian di SMA Negeri 7 Merangin. Berdasarkan fenomena tersebut terdapat fenomena konsep diri. Berdasarkan pembagian angket tabel 1.1 bahwa sekitar $62,5 \%$ atau 25 orang responden yang mengatakan ya bahwa ada masalah mampu mengatasinya dengan tenang dan sekitar 15 orang yang mengatakan tidak dari 40 orang responden, berikutnya $50 \%$ atau 20 orang responden yang menjawab ya yang mempunyai keyakinan dalam menghadapi masalah dan ada 20 orang atau $50 \%$ dari 40 responden yang mengatakan tidak, ada sebanyak 15 orang responden berkata ya selalu merasa percaya diri dan menganggap sederajat dengan orang lain yang mengatakan tidak ada sekitar 25 orang responden, dan sekitar 10 orang yang mengatakan ya bahwa merasa saya berharga dari orang lain dan ada sekitar 30 orang responden yang mengatakan tidak, ada sekitar 20 orang responden yang mengatakan ya bahwa yang menerima segala pujian dari siapa pun dengan senang hati dan sekitar 20 responden berkata tidak, seterusnya sekitar 25 orang responden mengatakan ya bahwa ada juga yang tidak merasa malu akan keadaan dirinya dan selalu menerima pujian maupun kritikan sekitar 15 orang responden yang mengatakan tidak, kemudian sekitar 10 orang responden yang mengatakan ya bahwa kelemahan di milikinya tidak membuatnya menyalahkan dirinya sendiri, dan sekitar 30 orang yang mengatakan tidak setuju, dan juga sekitar 18 orang yang mengatakan ya bahwa sanggup meletakkan dirinya pada kondisi yang sesuai, dan ada juga sekitar 22 orang yang mengatakan tidak, kemudian ada juga sekitar 28 orang mengatakan ya tetap mengoreksi dirinya apabila terdapat kesalahan, dan ada juga sekitar 12 orang yang tidak setuju atau mengatakan tidak, dan terakhir ada juga sekitar 20 orang yang mengatakan setuju dengan bertanggung jawab atas apa yang telah dilakukan, dan ada juga sekitar 20 orang responden yang tidak setuju.

Tabel 1.1 Data Observasi Awal Konsep Diri

\begin{tabular}{|c|c|c|c|c|c|c|}
\hline xea & 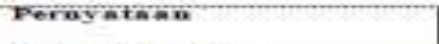 & $\begin{array}{l}\text { Tainheh } \\
\text { orabe }\end{array}$ & $5 \%$ & 76 & Trane & $86^{\circ}$ \\
\hline & 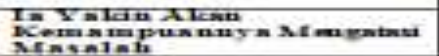 & & & & & \\
\hline$T$ & Apabiti san masalah says & $+\infty$ & 25 & $82.3 \% 5$ & 13 & $373 \%$ \\
\hline 2 & 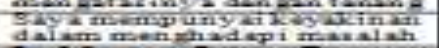 & $=0$ & 20 & 3000 & 20 & 3056 \\
\hline & 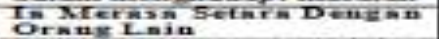 & & & & & \\
\hline 3 & 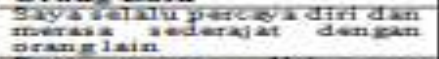 & $=0$ & 15 & $37.5 \%$ & 25 & 62.575 \\
\hline 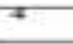 & 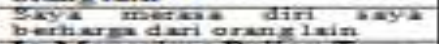 & $\$ 0$ & 10 & 2506 & 30 & $73 \% 6$ \\
\hline & 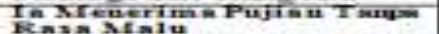 & & & & & \\
\hline 3 & 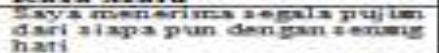 & 40 & 20 & $30 \% 6$ & र्र० & इ0\% \\
\hline क & 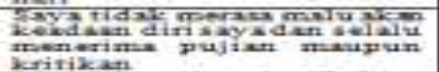 & +0 & 23 & $02,3 \%$ & T3 & $273 \%$ \\
\hline & 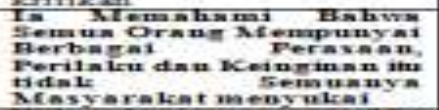 & & & & & \\
\hline 7 & 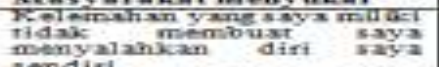 & +0 & 10 & $25 \%$ & ग0 & 7396 \\
\hline 9 & 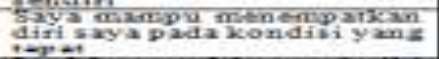 & 50 & 15 & 6395 & 22 & $539 \%$ \\
\hline & 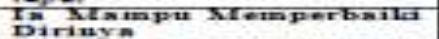 & & & & & \\
\hline g & 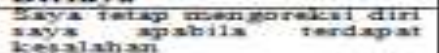 & 40 & $2 \pi$ & $70 \%$ & 12 & $30=6$ \\
\hline 10 & 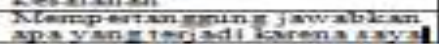 & $\$ 0$ & 20 & $50 \%$ & 70 & 50\% \\
\hline
\end{tabular}


Berdasarkan data tabel 1.1 di atas menjelaskan tentang konsep diri siswa hasil data awal pada SMA Negeri 7 Merangin keadaan pembelajaran siswa itu sendiri belum optimal, dikarena kan kurangnya percaya diri dalam diri siswa dan sedikitnya keyakinan dalam diri siswa.

(Ahmad Susanto, 2018: 286-288) keyakinan individu terhadap keberhasilannya dapat dikembangkan oleh empat faktor utama, yaitu:

1) Pengalaman Penguasaan (Mastery Experince)

Pengaruh pertama dalam membentuk dan memperkuat diri individu adalah pengalaman penguasaan. Kesuksesan sebagai hasil dari pengalaman penguasaan, akan membangun kepercayaan yang dalam keyakinan pribadi individu. Sebaliknya, kegagalan akan mengurangi rasa keyakinan individu.

2) Pengalaman Perumpamaan (Vicarious Experiences)

Pengaruh yang kedua dalam membentuk dan memperkuat diri individu adalah pengalaman yang diperoleh melalui pengamatan terhadap model sosial.

3) Persuasi Sosial atau Verbal (Social Persuasion)

Persuasi ini bisa menguatkan diri individu guna pencapaian keberhasilan. Pendapat orang lain yang menganggap individu memiliki kemampuan dalam menyelesaikan suatu kegiatan dengan sukses akan meperkuat keyakinan diri individu dalam menghadapi berbagai masalah atau tantangan ketika melaksanakan suatu kegiatan/aktivitas.

4) Kondisi Psikologis dan Emosional ( Physicological and Emotional States)

Sumber diri individu yang terakhir adalah keadaan fisiologos dan emosional. Menurut Bandura (1995: 4) kegiatan yang melibatkan kekuatan dan stamina, individu cenderung menilai kelelahan fisik sebagai kelemahan suasanan hati mempengaruhi penilaian individu tentang kompetensi dirinya.

Kayakinan atau pemahaman terhadap diri sendiri (individu) menentukan akan sebuah dorongan belajar siswa dengan kata lain motivasi. Siswa akan termotivasi bila keyakinan dirinya baik, karena keyakinan di diri setiap pelajar berguna untuk memacu agar lebih giat belajar.

Adapun motivasi menurut Ahmad susanto (2018: 31), yaitu perilaku termasuk situasi yang mendorong, dorongan yang timbul serta tingkah laku yang dan seluruh gerakan atau perbuatan siswa. Siswa terdorong untuk belajar lebih giat lagi karena ingin (termotivasi) mendapatkan nilai lebih baik, ingin meningkatkan prestasi yang lebih baik dari sebelumnya, juga seseorang dapat bekerja lebih giat lagi karena termotivasi memperbaiki kondisi hidupnya didalam lingkungan sekitarnya. Orang yang termotivasi juga dikarenakan mempunyai pemahaman dan keyakinan yang bagus terhadap dirinya sendiri.

Dengan kata lain, motivasi juga diartikan dengan segala dorongan yang timbul di diri individu guna meraih tujuannya dengan baik. Peneliti membagikan angket motivasi belajar pada responden tanggal 03 Maret 2019 pada tabel berikut,

\section{Tabel 1.2 Data Observasi Awal Motivasi Belajar}

\begin{tabular}{|c|c|c|c|c|c|c|}
\hline Nos & $x=2000=6-10=0$ & 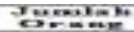 & $x=$ & क6 & Thas he & $\infty$ \\
\hline & 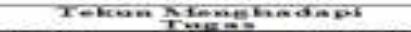 & & & & & \\
\hline$T$ & 5axa & मक & 20 & उ०क्त & 100 & इखण्य \\
\hline$=$ & 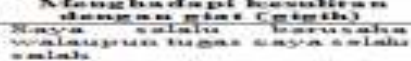 & 40 & 100 & $=3 \times 5$ & 30 & 7045 \\
\hline 3 & 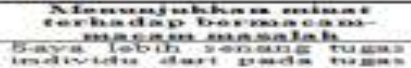 & 40 & 18 & $45 \times 6$ & 22 & 5क्य \\
\hline & 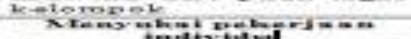 & & & & & \\
\hline 7 & 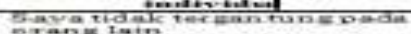 & 40 & 25 & $0=2.350$ & 15 & $3, .50$ \\
\hline & 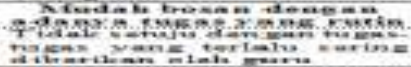 & ras. & $r>$ & 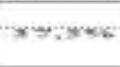 & 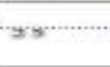 & 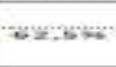 \\
\hline न & м-n. & 25 & sa & $70 \times 6$ & ra & seक्ष \\
\hline & 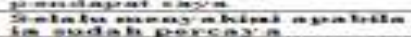 & & & & & \\
\hline 7 & 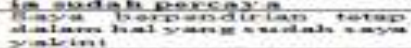 & to & 75 & कश्र.306 & ry & 57,056 \\
\hline I & 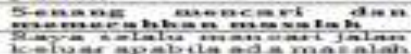 & to & 20 & 300 & 20 & करवस \\
\hline
\end{tabular}


Berdasarkan pembagian angket tabel 1.2 tanggal 03 Maret 2019 bahwa ada sebanyak 20 orang dari 40 responden yang menjawab ya bahwa mengeluh apabila guru memberi tugas dan terdapat 20 responden dengan jawaban tidak, kemudian 10 orang memberi jawaban ya bahwa yang selalu berusaha walaupun tugas selalu salah dan sebanyak 30 orang responden yang berkata tidak, seterusnya ada sebayak 18 orang responden yang mengatakan ya bahwa yang lebih senang tugas individu dari pada tugas kelompok dan didapati 22 orang responden yang beri jawaban tidak, dan diketahui 25 orang responden bilang ya bahwa tidak tergantung pada orang lain dan berjumlah 15 responden bilang tidak, selanjutnya sebanyak 15 orang responden beri jawaban ya bahwa tidak menyukai tugas-tugas yang terlalu sering diberikan oleh guru dan ditemui 25 responden beri jawaban tidak, selanjutnya lagi didapati 30 responden yang menjawab ya bahwa berusaha gigih dalam pendapatnya dan sebanyak 10 responden berkata tidak, selanjutnya ada sebanyak 25 responden mengatakan ya bahwa berpendirian tetap dalam hal yang sudah di yakini dan diketahui 15 responden memebri jawaban tidak, dan yang terakhir dijumpai 20 responden yang menjawab ya bahwa selalu mencari jalan keluar apabila ada masalah dan terdapat 20 responden bilang tidak.

Rendahnya motivasi belajar salah satu diakibatkan kurangnya keyakinan siswa terhadap diri nya sendiri dan masih banyak juga apabila diberikan tugas oleh guru dan siswa itu sendiri mengeluh serta siswa banyak bergantung pada orang lain dan tidak mau berusaha sendiri, maka itulah yang menyebabkan rendahnya semangat siswa dalam belajar.

Dari observasi yang penelitian lakukan di SMA Negeri 7 Merangin selama proses pembelajaran menunjukkan keyakinan siswa terhadap dirinya sendiri yang masih rendah. Konsep diri merupakan segala sesuatu bentuk yng dilihat terhadap diri seseorang untuk melihat seperti apa dirinya (Uno dalam Ahmad: 32)

Menurut Maslow (Hamzah, 2010:40) yang ditujukan, Maslow membagikan 5 kategori di dalam teorinya tersebut adalah:

1) Teori hierarki (kebutuhan maslow)

a) Kebutuhan fisiologikal (physiological needs)

Merupakan manusia yang paling penting dan paling berguna yang mana anatara nya yaitu kebutuhan akan makanan, pakaian.

b) Kebutuhan Rasa tenang (safety needs)

Merupakan kebutuhan rasa diri akan rasa nyaman serta merasa bahwa dirinya tidak terganggu.

c) Kebutuhan akan kasih sayang (love needs)

Merupakan kebutuhan hubungan atau keterkaitan terhadap orang lain.

d) Kebutuhan pujian (esteem needs)

Merupakan kebutuhan pujian yang bermanfaat.

Dari teori yang diuraikan dapat di simpulkan bahwa motivasi belajar memiliki sebuah kebutuhan dan kepuasan, setiap kebutuhan yang didalam lebih ke diri individu tersebut maka dari itu motivasi belajar akan memiliki pengaruh yang besar untuk kegiatan yang ingin dilakukannya agar mencapai tujuan yang diinginkan nya.

\section{2) Teori Kehadiran, Hubungan, Dan Pertumbuhan Alderef}

Menurut Aldefer (Hamzah, 2010:43) menjelaskan teori yang ditujukan Maslow tersebut. Alderef mengatakan bahwa dalam teorinya ada dua macam yaitu :

a) Kebutuhan berkaitan dengan hubungan kemitraan

b) Kebutuhan pertumbuhan

Dimaksud pertumbuhan ialah suatu hal yang dibutuhkan dalam perkembangan potensi seseorang. 
Didalam teori Alderef ini dapat disimpulkan bahwa pendapat ini sangat erat kaitan dan sangat berhubungan dengan teori hierarki Maslow dan juga di dalam teori ini lebih kedalam diri individual siswanya tersebut.

Adapun jenis motivasi Sardimaan (2014:86) antara lain:

1) Motivasi berdasarkan prosesnya

a) Motif-motif yng pelajari

Segala sesuatu bentuk didapat ataupun diperoleh dari pembelajaran atau dipelajari.

2) Motivasi menurut pembagiannya

a) Motif atau kebutuhan organis

Yang berdasarkan pemenuhan kondisi fisik ataupun organ seseorang. Seperti: bernapas, makan, minum serta kebutuhan beristirahat.

b) Motif darurat

Motif ini merupakan kedaan terdesak pada manusia. Seperti: menyelamatkan diri.

c) Motif objektif

Artinya kebutuhan yang menyangkut manipulasi, eksplorasi. Dorongan dari luar secara efektif sehingga meimbulkan motif ini .

3) Berdasarkan tubuh dan rohani

a) Timbulnya alasan

Timbulnya alasan adalah dimana alasan seseorang dimana tidak mengecewakan orang lain.

b) Momen memihak

Artinya yaitu dimana keadaan harus memilih salah satu diantara banyaknya aternatif yang ada.

c) Momen putusan

Yaitu dibilang momen putusan apabila momen akhir maka dipilih satu altenatif yang akan dipilih, maka itu dikatakan momen putusan untuk selanjutnya.

4) Instrinsik dan ekstrinsik

a) Intrinsik

Terjadi adanya pengaruh ataupun dorongan dari pihak lain

b) Ekstrinsik

Motif-motif yg aktif terjadi oleh rangasangan ataupun dorongan dari manapun.

Berdasarkan jenis motivasi yang di sampaikan oleh sardiman dapat disimpulkan bahwa motivasi bisa dilihat akan pada dorongan atau kekuatan seseorang seperti motivasi intrinsik. Karena intrinsik tidak perlu di rangsang dari luar melainkan sesuatu dorongan dari diri sendiri atau individu sendiri, sedangkan ekstrinsik memerlukan rangsangan dari luar atau memerlukan bantuan dengan lingkungan yang bagus

Adapun bentuk dalam membangkitkan motivasi siswa, Sardiman (2006: 91) diantaranya:

1) Pemberian angka

Yaitu pemberian apa yang ia lakukan atau yang sering disebut dengan penilaian.

2) Hadiah

Hadiah ialah sesuatu bentuk yang dapat membuat siswa termotivasi karna penghargaan atas hasil yang telah dicapainya.

3) Saingan/kompetisi

Merupakan suatu motivasi siswa karna adanya lawan untuk saling menunjukkan mana yang terbaik dianatar mereka.

4) Ego-involvement

Merupakan suatu dorongan dalam diri siswa untuk menghadapi serta menerima akan tantanganyang dihadapinya.

5) Memberi ulangan

Bentuk motivasi ini ialah dengan memberikan tugas sehingga membuat siswa lebih giat untuk apa yang diinginkannya. 
6) Melihat hasil

Dengan melihat hasil pekerjaan yang kita lakukan dan jika terjadi kemajuan, itulah yang mendorong siswa untuk mencapai sesuatu yangmenjadi tujuannya.

7) Pujian/ penghargaan

Merupakan suatu bentuk pengakuan diperoleh.

8) Hukuman/balasan negatif

Agar seseorang menyadari dengan apa yang telah ia lakukan.

9) Keinginan untuk belajar

Keinginan disetarakan motivasi.

10) Minat/ bakat

Bakat pada diri seseorang untuk berubah lebih baik.

11) Tujuan yang dipahami

Hal yang ingin dicapainya.Teori diatas mengenai bentuk-bentuk motivasi yang dikemukakan oleh Sardiman (2006:91-95) bahwa untuk mempermudah jalannya penelitian ini maka peneliti membatasi bentuk-bentuk motivasi sebagai induksi dari motivasi belajar yaitu: minat belajar, saingan atau kompetensi dikelas, hasrat belajar, gairah belajar, memberi ulangan buat siswa, mengetahui hasil kegiatan siswa dalam kegiatan belajar.

\section{KAJIAN PUSTAKA}

Kajian Pustaka dalam suatu pengaturan karya tulis ilmiah dapat diartikan sebagai penegasan terhadap keterbatasan karya ilmiah. Intisari dalam bagian ini dimuat secara lengkap di keyoword di bagian abstrak. Karena itu, persiapan karya tulis apa pun harus diwajibkan membuat studi literatur.

Agar tidak dianggap plagiarisme dari karya orang lain, penting bagi siapa pun untuk membuat tinjauan literatur dengan menulis ulang bahasa dan kata-kata yang diperoleh di bagian pencarian literatur. Sangat mudah untuk menggunakan kutipan langsung atau tidak langsung.

\section{METODE PENELITIAN}

Penelitian ini mengunakan metode kuantitatif. Metode ini menggunakan cara pandang peneliti kepada alam, yang digunakan peneliti. Analisis dilaksanakan dengan cara regresi sederhana. Adapun tujuannya agar diketahui seberapa besar konsep diri mempengaruhi Motivais belajar siswa sebanyak 50 orang siswa.

Instrument penelitian membutuhkan angket sebanyak 50 angket lalu diberikan kepada 50 orang yang menjadi responden. Dan penelitian menggunakan skala pengukuran angket yaitu skala likert yang seterusnya dianalisis menggunakan pengujian validitas dan realibiltas. Jika proses pengujian berhasil, instrument tersebut baru dijadikan sebagai penelitian ke 50 responden setelah itu dilaksanakan pengujian lain, seperti normalitas, linieritas, hingga regresi sederhana dan pengujian hipotesis $(\mathrm{t})$.

\section{HASIL DAN PEMBAHASAN}

Persoalan yang diungkap di penelitian ini antara lain berapa banyak konsep diri mempengaruhi motivasi belajar siswa SMA Negeri 7 Merangin tahun 2019/2020. Berdasarkan perhitungan statistik variabel $X$ yaitu besarnya konsep diri siswa (X) ke motivasi belajar (Y) yaitu 3,052 > t tabel 1,995, ini berarti hipotesis yang menyebutkan "Adanya secara signifikan pengaruh antara konsep diri dengan motivasi belajar" atau Ha diterima. Sedangkan hipotsis yang menyebutkan" pengruh yang signifikan tidak terdapat di antara konsep diri dengan motivasi belajar" berarti Ho ditolak. Maka diartikan konsep diri berbanding lurus dengan motivasi belajar siswa di SMA Negeri 7 Merangin. Hasil dari Tingkat Capaian Jawaban Responden (TCR) yang diperoleh dalam penelitian ini. Pada 
variabel Konsep Diri, nilai Tingkat Capaian Jawaban Responden berada pada kriteria tinggi dengan rara-rata skor sebesar 4,4 dan tingkat capaiannya sebesar 88,53\%. ini artinya konsep diri siswa SMA N 7 Merangin dinilai baik. Sedangkan pada variabel Motivasi Belajar nilai Tingkat Capaian Jawaban Responden juga berada pada kategori sangat tinggi, yaitu rata-rata skor 4,5 dan tingkat capaian sebesar 91,4\%. ini artinya motivasi belajar siswa SMA Negeri 7 Merangin dinilai sangat tinggi.

Tabel 1.3 Tingkat capaian

\section{Responden (TCR) Variabel Konsep Diri}

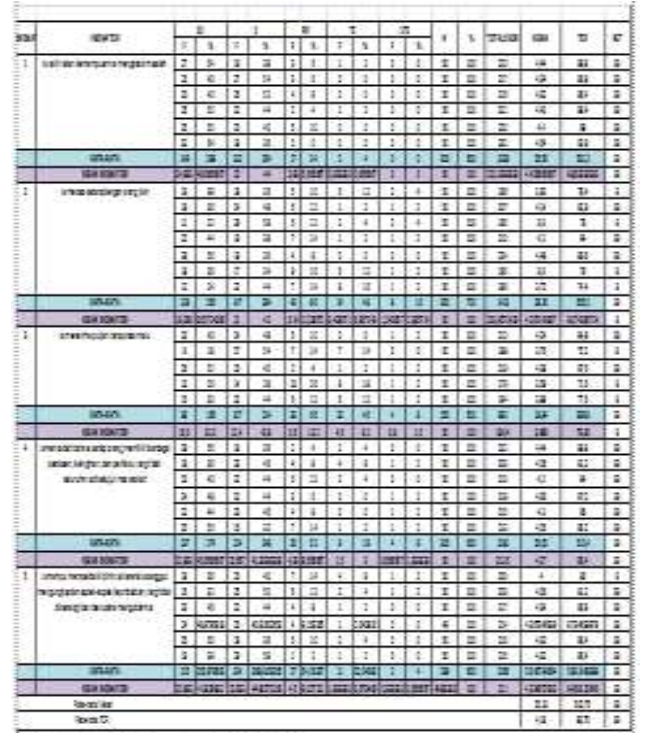

Sumber : Data Olahan 2019

Dari tabel tersebut ditemui informasi skor rata ata untuk variabel X Konsep Diri adalah sebesar adalah sebesar 4,4 dan tingkat capaian sebesar 88,53\%. Ini artinya konsep diri siswa SMA Negeri 7 Merangin dinilai sangat baik. Selanjutnya.

\section{Tabel 1.4 Tingkat capaian}

Responden (TCR) Variabel Motivasi Belajar

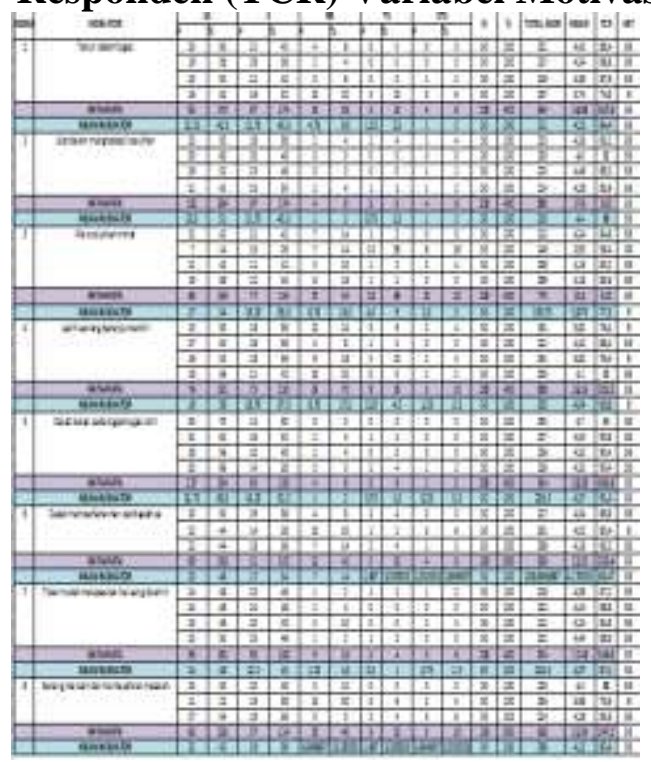

Sumber : Data Olahan 2019 
Tabel 1.4 memperlihatkan tingkat capaian jawaban responden (TCR) variabel motivasi belajar 4,5 dan tingkat capaian sebesar 91,4\%. Ini artinya motivasi belajar SMA Negeri 7 Merangin dinilai sangat baik

Analisis yang selanjutnya adalah uji normalitas. Adapun maksud uji normalitas untuk memeriksa setiap data dari populasi terdistribusi normal atau tidak. Pengujian dilakukan sebagai suatu persyaratan terpenting yang harus terpenuhi di dalam analisis regresi sederhana. Pedoman di dalam uji normalitas adalah uji kolmogrov smirnov menurut Idris:

Tabel 1.5 Kesimpulan Uji

Normalitas

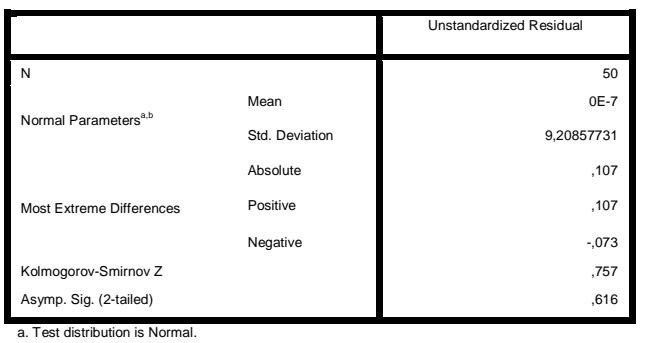

b. Calculated from data.

Sumber: Data Primer, 2019 (Di olahan dengan SPSS Versi 20)

Menunjukkan bahwa nilai signifikansi untuk semua variabel 0,616 >0.05, ini artinya semua variabel datanya berdistribusi secara normal. Maka analisis regresi sederhana dapat dilaksanakan. Diketahui nilai signifikansi probability untuk semua variabel, baik variabel dependen maupun independen besar dari $\alpha$ 0,05, maka semua variabel berdistribusi normal. Berarti regresi linier sederhana bisa dilaksanakan.

Tabel 1.6 Kesimpulan Uji

Linearitas

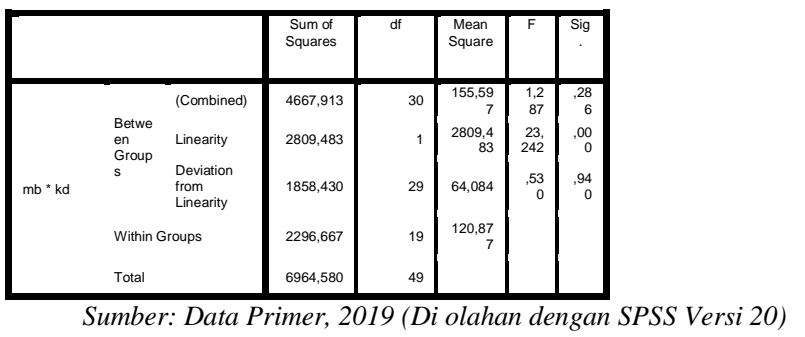

Berdasarkan Tabel 1.6 dapat diketehui bahwa nilai 0,616>0,05 artinya 0,616 lebih besar dari 0,05 maka signifikansi linearity berlaku keseluruhan variabel. Keseluruhan variabel baik itu dependent maupun independent besar dari $\alpha 0,05$. Dengan kata lain semua variabel adalah linier. Berarti analisis data menggunakan analisis linearity dapat dilaksanakan.

Tabel 1.7 Kesimpulan Uji regresi sederhana

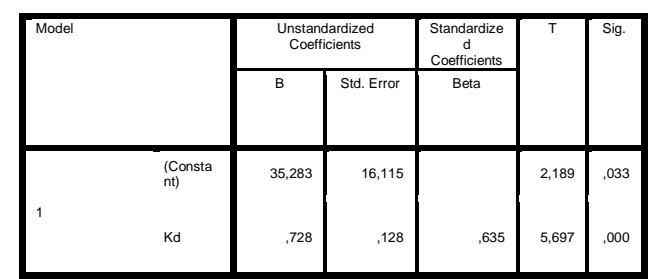

a. Dependent Variable: mb 
Sumber : Data Primer,2019 (Di olahan dengan SPSS Versi 20)

Dari tabel di atas bisa diperoleh persamaan regresi yaitu berdasarkan nilai caonstant (a) sebesar 35,283 sedangkan nilai konsep diri sebesar 0,728 dapat ditulis:

$\mathrm{Y}=\mathrm{a}+\mathrm{bx}$

$\mathrm{Y}=35,283+0,728 \mathrm{x}$

Persamaan diatas dimaksud yaitu:

1. Konstanta sebesar 35,283 mengandung arti bahwa nilai konsisten variabel konsep diri adalah sebesar 35,283.

2. $0,728 \mathrm{x}$ atau analisis dari konsep diri yang secara signifikan berpengaruh ke motivasi belajar.

Selain penjelasan regresi sederhana ini bisa dimulai dengan melihat R-squared seperti Tabel 1.8

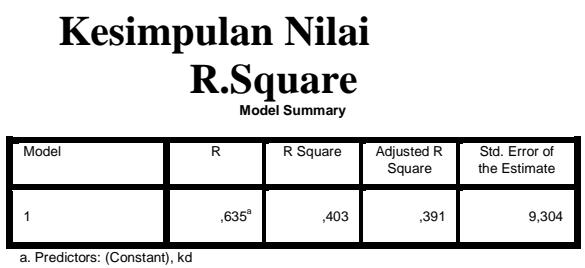

Sumber : Data Primer Olahan,2019(Di Olahan SPSS 20)

Dalam Tabel 1.8 dapat diketahui bahwa $\mathrm{R}$ Square pada regresi sederhana pada $\mathrm{R}$ yang telah menunjukkan tingkat hubungan antara independen konsep diri (X) dan dependen motivasi belajar (Y) yaitu: 0,403 atau sebesar 40,5\% dari motivasi belajar terhadap konsep diri sedangkan 59,5\% lainnya terdapat pengaruh dari faktor lain yaitu kondisi fisik lingkungan belajar siswa tidak memnuhi kategori baik dan peralatan perlengkapan belajar tidak memadai itulah yang menyebabkan rendahnya motivasi belajar siswa. Selain itu juga bisa dilihat pada uji hipotesis (uji t) pada tabel 1.9

\section{Tabel 1.9 Hasil Pengujian Uji t}

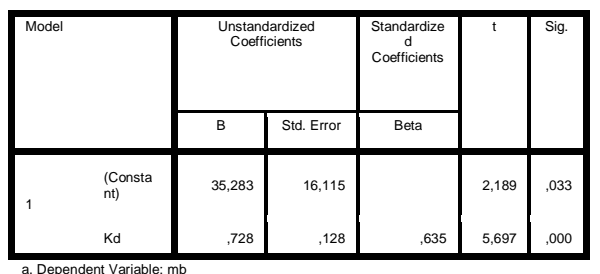

Sumber : Data Primer olahan, 2019 (Di Olahan SPSS 20)

Didapati dari pengujian $t$ tabel : untuk variabel $X$ (konsep diri) diperoleh thitung $=5,697$. Dengan menggunakan batas signifikan $\alpha=0,05$. Dari hasil tersebut maka kreteria yaitu thitung $<$ dari tabel yang artinya Ha diterima Ho ditolak. Dengan demikian hipotesis uji t variabel $\mathrm{X}$ secara signifikan negatif mempengaruhi variabel Y. Jadi disimpulkan indikator konsep diri berpengaruh ke motivasi belajar.

Berdasarkan perhitungan statistik besarnya hubungan konsep diri (X) terhadap motivasi belajar (Y) yang menunjukkan bahwa t hitung $(5,697)>t$ tabel $(1,684)$, ini berarti hipotesis yang menyimpulkan "ditemui pengaruh signifikan antara konsep diri terhadap motivasi belajar" atau Ha diterima. Sedangkan hipotsis yang menyatakan "tidak ada pengaruh yang signifikan antara konsep diri terhadap motivasi belajar" berarti Ho ditolak. Ini artinya, semakin tinggi konsep diri dengan motivasi belajar yang dimiliki oleh siswa SMA Negeri 7 Merangin berbanding lurus, yaitu konsep diri tinggi berdampak dengan motivasi belajar siswa yang tinggi. Hasil dari Tingkat Capaian Jawaban Responden (TCR) yang diperoleh dalam penelitian ini. Pada variabel Konsep Diri, nilai Tingkat Capaian Jawaban Responden 
berada pada kriteria tinggi dengan rara-rata skor sebesar 4,4 dan tingkat capaiannya sebesar 88,53\%. ini artinya konsep diri siswa SMA N 7 Merangin dinilai baik. Sedangkan pada variabel Motivasi Belajar nilai Tingkat Capaian Jawaban Responden juga berada pada kriteria sangat tinggi dengan rata-rata skor sebesar 4,5 dan tingkat capaian sebesar 91,4\%. ini artinya motivasi belajar siswa SMA Negeri 7 Merangin dinilai sangat tinggi.

\section{KESIMPULAN DAN SARAN}

Dapat disimpulkan beberapa dari penelitian ini adalah berdasarkan hasil dari analisis konsep diri terhadap motivasi belajar siswa yang sudah diuraikan pada bab sebelumnya, dimana terdapat variabel independen konsep diri punya pengaruh positif ke motivasi belajar siswa. Jadi bisa disimpulkan indikator konsep diri siswa yng semakin membaik akan menumbuhkan motivasi siswa yang baik pula dalam belajar.

Adapun saran yang dapat dikemukakan:

1. Pengujian yang dilakukan bahwa konsep diri siswa berpengaruh positif terhadap motivasi belajar siswa kelas XI dan XII IPS. Maka diharapkan kepada SMA 7 Negeri Merangin agar tetap mempertahankan dan mampu meningkatkan kualitas konsep diri pada siswa sehingga bisa memberikan dampak yang positif bagi sekolah kedepannya.

2. Bagi sekolah, untuk masukan bagi guru agar dapat melihat konsep diri dan motivasi belajar pada siswa.

3. Bagi lembaga STKIP YPM Bangko,dari hasil penelitian ini bisa menjadi acuan untuk meningkatkan konsep diri mahasiswa yang ada dikampus agar bisa menjadi lebih baik lagi.

4. Bagi peneliti, dapat mencari tahu tentang seberapa besar pengaruh konsep diri siswa di SMA Negeri 7 Merangin.

\section{DAFTAR RUJUKAN}

Susanto Ahmad. 2018. Bimbingan dan Konseling di Sekolah Konsep, Teori, dan Aplikasinya. Jakarta : PRENADAMEDIA GROUP.

Undang-Undang RI 20 Tahun 2003. Sistem pendidikan nasional (SISDIKNAS).

Uno, Hamzah B. 2010. Teori Motivasi dan Pengukurannya Analisis di Bidang Pendidikan. Jakarta : PT Bumi Aksara. 